\title{
Inisiatif Pengembangan BUMDesa sebagai Wirausaha Sosial
}

\author{
M. Zamzam Fauzanafi dan Bambang Hudayana
}

Departemen Antropologi, Fakultas Ilmu Budaya, Universitas Gadjah Mada

Korespondensi: muhammad.zamzam.f@ugm.ac.id

\section{Tim Pengabdian Masyarakat}

Heddy Shri Ahimsa Putra, Irwan Abdullah, G.R. Lono Lastoro Simatupang, Mubarika D.F. Nugrahaeni, P. M. Laksono, Pande Made Kutanegara, Pujo Semedi, Sita Hidayah

\begin{abstract}
One of the mandates of Undang-Undang No. 6 Tahun 2014 tentang Desa is the establishment of $B U M D e s$ (Village-Owned Enterprises) as village businesses that are used for village income sources. The process of establishing the BUMDes was colored by efforts of various stakeholders to place this business entity as an important element in economic development and to have social benefits. BUMDes is expected to have a vision and mission as a social entrepreneur so that it can empower small and micro scale businesses (UKM) and marginalized communities. During 2015 until now, villages have moved to have BUMDes, but in general villages have not succeeded in forming and managing BUMDes as social entrepreneurs. The Community service activity encourage BUMDes to have a role as social entrepreneurs so that the existence of BUMDes is very relevant to improve the welfare and empowerment of small and marginal communities. The activities that have been carried out are a training and field visits which are participated by BUMDesa managers in several villages in D.I. Yogyakarta. The results of community service activities are: change in orientation and role of BUMDesa from village business for village government to village business for village people, $B U M D$ esa synergizing with village institutions as an effort to improve community welfare especially in local economic development, and BUMDesa development with social entrepreneurship vision.
\end{abstract}

Keywords: BUMDes; socio-preneur; village people; local economy

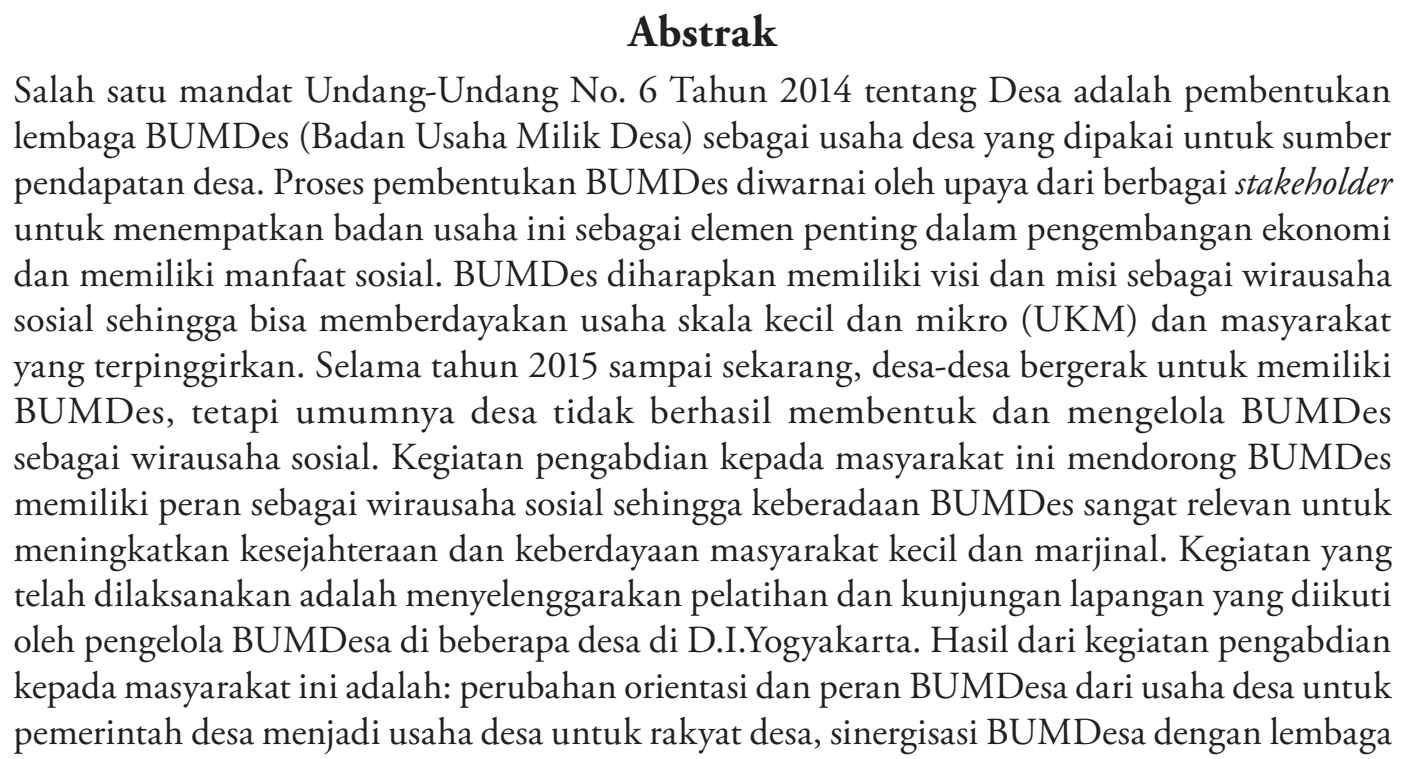


desa sebagai upaya peningkatan kesejateraan masyarakat khususnya dalam pengembangan ekonomi lokal, dan pengembangan BUMDesa yang bervisi wirausaha sosial.

Kata kunci: BUMDes; wirausaha sosial; rakyat desa; ekonomi lokal

\section{Pendahuluan}

Pengembangan BUMDesa menuju wirausaha sosial merupakan agenda dari Tri Dharma Perguruan Tinggi dengan tujuan untuk mewujudkan hilirisasi penelitian agar berguna bagi pembangunan sosial budaya. Pengembangan BUMDesa ini relevan dengan munculnya permasalahan seperti tingginya angka kemiskinan (10\%) serta banyaknya kelompok rentan dan usaha skala kecil dan mikro (UKM) yang dapat terdampak negatif oleh hadirnya BUMDesa bila tidak memiliki visi dan misi pemberdayaan masyarakat. Untuk itulah, pemberdayaan masyarakat ini memanfaatkan pengetahuan dosen, asisten, dan mahasiswa dalam menerapkan ilmu, teori, serta instrumen, khususnya di bidang pengembangan wirausaha sosial.

Pusat Kajian Dinamika Sistem Pembangunan Fakultas Ekonomi dan Bisnis, Universitas Brawijaya menyatakan gagasan mengenai wirausaha sosial. Sebagai sebuah wirausaha sosial (PKDSP, 2007), terdapat ciri utama yang membedakan BUMDesa dengan lembaga ekonomi komersial lainnya. Ciri tersebut adalah sebagai berikut.

- BUMDesa dimiliki oleh desa dan dikelola secara bersama.

- Modal usaha BUMDesa bersumber dari desa (51\%) dan dari masyarakat (49\%) melalui penyertaan modal (saham atau andil).

- Operasionalisasi BUMDesa menggunakan falsafah bisnis yang berakar dari budaya lokal (local wisdom).

- Bidang usaha yang dijalankan didasarkan pada potensi dan hasil informasi pasar.

- Keuntungan yang diperoleh BUMDesa ditujukan untuk meningkatkan kesejahteraan anggota (penyerta modal) dan masyarakat melalui kebijakan desa (village policy).

- BUMDesa difasilitasi oleh Pemerintah, Pemerintah Provinsi, Pemerintah Kabupaten, dan Pemerintah Desa.

- Pelaksanaan operasionalisasi dikontrol secara bersama (Pemerintah Desa, BPD, dan tim pengelola BUMDesa).

Gagasan PKDSP tersebut menunjukkan bahwa BUMDesa seharusnya membuka akses bagi warga untuk ikut menanamkan modal sekaligus keuntungan yang dialokasikan bagi kesejahteraan masyarakat terpinggirkan. Gagasan itu bergayungsambut dengan berbagai LSM yang menekankan petingnya BUMDesa untuk memberikan manfaat sosial-ekonomi bagi masyarakat. Beberapa LSM terus menekankan pentingnya asas manfaat pada pendirian BUMDesa, yang bukan hanya fokus pada keuntungan finansial semata. Hadirnya Undang-Undang Desa telah memperkuat mandat desa untuk mengembangkan BUMDesa bukan semata-mata sebagai sumber pedapatan desa. Namun, dalam pelaksanaannya, desa tidak memiliki orientasi yang kuat untuk menempatkan BUMDesa sebagai kekuatan ekonomi rakyat sehingga manfaat sosial dari BUMDesa belum bisa terukur dengan baik. 
Catatan dari berbagai sumber mengemukakan bahwa BUMDesa lebih menonjol sebagai proyek daripada program, dalam arti BUMDesa menjadi bisnis desa yang kurang relevan untuk memberdayakan ekonomi rakyat karena keuntungan BUMDesa dimanfaatkan oleh pemerintah desa, tetapi tidak berimbas pada pembangunan sosialekonomi. Hanya beberapa BUMDesa yang kemudian bergaung di media dan dianggap sebagai BUMDesa teladan karena telah menjalankan kiprah sebagai wirausaha sosial dan berdampak positif terhadap pembangunan sosial ekonomi desa. BUMDesa tersebut misalnya BUMDesa Karangrejek, Kecamatan Wonosari, Kabupaten Gunung Kidul.

Sedikitnya BUMDesa yang memiliki visi dan misi wirausaha sosial dapat dimengerti karena minimnya kapasitas, pengorganisasian masyarakat, konsolidasi antara pihak pemerintah dan dengan BPD, serta pelaku usaha di desa. Posisi pemerintah desa terlihat begitu kuat, tetapi miskin keberpihakan terhadap kepentingan pembangunan sosial, khususnya pemberdayaan masyarakat kecil.

Bertolak dari masalah tersebut, pemberdayaan BUMDesa menjadi sangat relevan dalam agenda pengabdian kepada masyarakat oleh tim Departemen Antropologi FIB UGM. Dilihat dari sisi filosofis, BUMDesa memiliki misi yang sama dengan koperasi, yaitu memajukan kesejahteraan rakyat, tetapi secara kelembagaan berbeda dengan koperasi maupun UMKM. BUMDesa lebih merupakan representasi lembaga formal milik desa yang bergerak di bidang perekonomian pada level desa, dengan pemisahan aset dari pemerintah desa. Akan tetapi, BUMDesa bisa menjadi payung yang memperkuat UMKM dan Koperasi. Sementara itu, dua unit usaha ini merupakan representasi kegiatan perekonomian nonformal yang langsung melekat pada masyarakat dan sering merepresentasikan ekonomi kerakyatan. Namun, mereka menghadapi masalah yang sama, yaitu harus bisa berdaya saing menghadapi meluasnya ekspansi pasar kapitalis. Kecenderungan mereka saling berlawanan dari bekerja sama untuk memberdayakan diri dan menghadapi ancaman dari meluasnya kapitalis di pedesaan. Departemen Antropologi FIB UGM akan bekerja mendorong para praktisi BUMDesa dan usaha mikro serta kecil di desa untuk melakukan pemetaaan masalah dan melakukan konsolidasi sehingga mereka bisa bergerak bersama, guna mewujudkan kerja sama yang sinergis untuk memperkuat perekonomian desa.

Dipilihnya beberapa pengurus BUMDesa sebagai ajang pemberdayaan adalah karena mereka merupakan pelaku penguatan BUMDesa. Program penguatan BUMDesa yang ditawarkan oleh proposal ini akan mengubah orientasi BUMDesa yang sangat formalistik, bisnis is usual, dan mengedepankan keuntungan untuk kemajuan keuangan pemerintah desa menjadi lebih berorientasi pada upaya memberdayakan ekonomi lokal, memberikan manfaat bagi pengurangan kemiskinan, kelompok yang terpinggirkan, dan sekaligus memperkuat daya tahan ekonomi desa di tengah meluasnya ekspansi kapitalisme.

Kegiatan pengabdian kepada masyarakat ini bertujuan untuk memperkuat peran BUMDesa menjadi wirausaha sosial desa. Adapun manfaat dari kegiatan ini adalah sebagai berikut. Pertama, adanya perubahan orientasi dan peran BUMDesa dari usaha desa untuk pemerintah desa menjadi usaha desa untuk rakyat desa. Kedua, sinergisasi BUMDesa dengan upaya utuk meningkatkan kesejateraan masyarakat, khususnya di bidang peningkatan akses UKM. Ketiga, meningkatnya inisiatif pengembangan wirausaha sosial di desa, di kalangan para pengelola BUMDesa di Daerah Istimewa Yogyakarta. 
Sasaran utama dari kegiatan pengabdian kepada masyarakat ini adalah 25 pengelola BUMDesa di desa-desa di Daerah Istimewa Yogyakarta. Para pengelola BUMDesa ini akan mendapatkan training mengenai wirausaha sosial dan merancang indikator BUMDesa wirausaha sosial. Sasaran sekunder dari kegiatan ini adalah masyarakat terpinggirkan (marjinal) karena mereka akan mendapatkan dampak lanjutan (impact) dari BUMDesa yang memiliki visi wirausaha sosial.

\section{Metode Pelaksanaan}

Pengabdian masyarakat ini menerapkan pendekatan action research (penelitian aksi) sebagai suatu penelitian terapan yang langsung melibatkan peneliti dan masyarakat marjinal sebagai kelompok sasaran untuk terlibat dalam proses perubahan, yang dirumuskan guna menjawab masalah yang dihadapi oleh masyarakat tersebut. Dengan demikian, penelitian aksi ini merupakan pengembangan Antropologi Terapan yang melibatkan antropolog untuk mengawal proses perubahan secara langsung (Hudayana, 2017).

Kerja penelitian aksi adalah menyediakan fasilitator untuk memudahkan masyarakat menemukan permasalahan dan bersama mereka menyusun serangkaian rencana aksi sekaligus mendampinginya agar mereka bisa lebih cepat, mudah, dan berhasil melakukan pemberdayaan. Fasilitasi yang dilakukan adalah pelatihan penguatan pengelola BUMDesa mengenai posisi dan peran BUMDesa sebagai wirausaha sosial dan kunjungan lapangan ke BUMDesa Karangrejek, Kecamatan Wonosari, Kabupaten Gunung Kidul.

\section{Pelaksanaan Program}

\section{Pelatihan Penguatan Pengelola BUMDesa}

Kegiatan pelatihan penguatan pengelola BUMDesa dilaksanakan pada Kamis, 3 Oktober 2019 di Pusat Studi Pedesaan dan Kawasan (PSPK)-UGM. Pelatihan ini menghadirkan narasumber Dr. Suharko dan D.C. Mulyono, M.A. dari PSPK. Acara ini dihadiri oleh praktisi BUMDesa di DIY dan Jawa Tengah.

Dalam pemaparannya, Dr. Suharko menyatakan bahwa berdasarkan undang-undang dan peraturan pemerintah, BUMDesa dibentuk dengan tujuan untuk kesejahteraan masyarakat desa. Hal itu tecermin dari definisi BUMDesa menurut UU No. 6 Tahun 2014 tentang desa bahwa "BUMDesa adalah badan usaha yang seluruh atau sebagian besar modalnya dimiliki oleh desa melalui penyertaan secara langsung yang berasal dari kekayaan desa yang dipisahkan guna mengelola aset, jasa pelayanan, dan usaha lainnya untuk sebesar-besarnya kesejahteraan masyarakat desa." Selaras dengan definisi tersebut, semangat yang harus dimiliki oleh BUMDesa adalah semangat kewirausahaan sosial untuk menjalankan usaha demi pembangunan sosial dan pemberdayaan masyarakat. Namun, realitas di lapangan menunjukkan bahwa banyak BUMDesa berorientasi menyimpang dari tujuan tersebut dan semata-mata hanya untuk memperoleh laba sebesar-besarnya. BUMDesa telah meninggalkan semangat kewirausahaan sosialnya dan beralih sebagai pelaku usaha yang semata-mata hanya mencari keuntungan.

Banyak faktor yang menyebabkan BUMDesa di desa semata-mata mengejar keuntungan usaha, salah satunya adalah motivasi dan orientasi pendirian BUMDesa. 
Karena ada anggapan dari para pihak, baik dari kalangan pemerintah maupun masyarakat, bahwa yang disebut BUMDesa yang baik adalah yang mampu mendapatkan keuntungan yang sebesar-besarnya, akhirnya banyak BUMDesa yang didirikan hanya untuk meraih keuntungan semata dan mengabaikan sisi pembangunan sosial dan pemberdayaan masayarakat.

Menurut Dr. Suharko, selain terjadinya pergeseran motivasi dan orientasi, persoalan lain yang dihadapi oleh BUMDesa adalah kegagalan serta ketidakmampuan BUMDesa untuk berkembang. Ada beberapa faktor yang menyebabkan BUMDesa gagal berkembang, yaitu adanya dominasi elite lokal; konflik pengelolaan aset dengan desa; pendirian BUMDesa tanpa musyawarah desa; pendirian BUMDesa tidak melalui kajian dan persiapan yang matang; hanya berorientasi jangka pendek; hanya berorientasi pada keuntungan untuk pendapatan asli desa; masuk ke bisnis yang persaingannya ketat; pendirian BUMDesa hanya merupakan program top-down yang bersifat massal atau penyeragaman dari Pemda; dan BUMDesa dikembangkan dengan akuisisi kegiatan ekonomi yang sudah berjalan.

Selain mencermati faktor penyebab kegagalan BUMDesa, Dr. Suharko juga mencermati faktor-faktor yang menyebabkan sebuah BUMDesa bisa berkembang dan meraih kesuksesan, yaitu kemampuan mengidentifikasi aset, potensi, kebutuhan, dan kegiatan ekonomi desa. Dari hasil identifikasi tersebut, BUMDesa memilih kegiatan ekonomi yang sesuai dengan kebutuhan warga masyarakat dan kegiatan ekonomi yang ada di desa, serta memanfaatkan semaksimal mungkin aset dan potensi yang dimiliki desa. Faktor lainnya adalah adanya masyarakat yang aktif; adanya komitmen pemerintah desa; pendirian BUMDesa disosialisasi dengan benar; tim kajian atau persiapan bekerja maksimal; pendirian BUMDesa memiliki alasan yang kuat; adanya social entrepreneurs di desa; adanya "Entrepreneur Bio", yaitu entrepreneur yang memiliki passion, keahlian, resilience, naluri bisnis dan keterampilan manajemen; dan adanya pendamping dari berbagai pihak.

Faktor kunci agar BUMDesa memiliki semangat kewirausahaan sosial adalah adanya pengelola BUMDesa yang mampu melaksanakan beberapa hal, yaitu mencoba mendobrak batasan ideologi dan disiplin; mengidentifikasi dan menerapkan solusi praktis untuk masalah sosial dengan menggabungkan inovasi, sumber daya, dan peluang; berinovasi dengan menemukan produk baru, layanan baru, atau pendekatan baru untuk masalah sosial; fokus pada penciptaan nilai sosial dan bersedia untuk mengembangkan berbagai inovasi serta wawasan agar orang lain dapat meniru; berani memulai sebelum memastikan sumber daya mencukupi; memiliki keyakinan teguh dalam kapasitas bawaan setiap orang; sering kali terlepas dari pendidikan untuk berkontribusi secara berarti bagi pembangunan ekonomi dan sosial; menunjukkan tekat yang mantap untuk mengambil risiko yang tidak berani dilakukan orang lain; menjaga keseimbangan antara semangat untuk berubah dan semangat untuk mengukur serta memantau dampaknya; memiliki banyak hal untuk sharing learning dengan pembuatan perubahan di sektor lain; dan menunjukkan ketidaksabaran yang kuat.

Adapun narasumber kedua, yakni D.C. Mulyono, M.A. menyampaikan bahwa berdasarkan UU Desa No. 6 Tahun 2014 tentang Desa dan PP No. 4 Tahun 2015 tentang BUMDesa, badan usaha ini dibentuk dengan tujuan untuk kesejahteraan masyarakat desa. Hal itu tecermin dari definisi BUMDesa yang dikatakan sebagai “badan usaha yang 


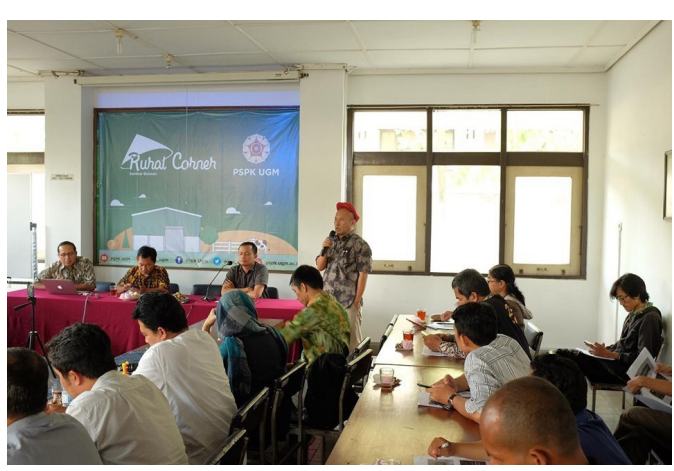

Gambar 1. Kegiatan pelatihan penguatan pengelola BUMDesa di Pusat Studi Pedesaan dan Kawasan (PSPK)-UGM.

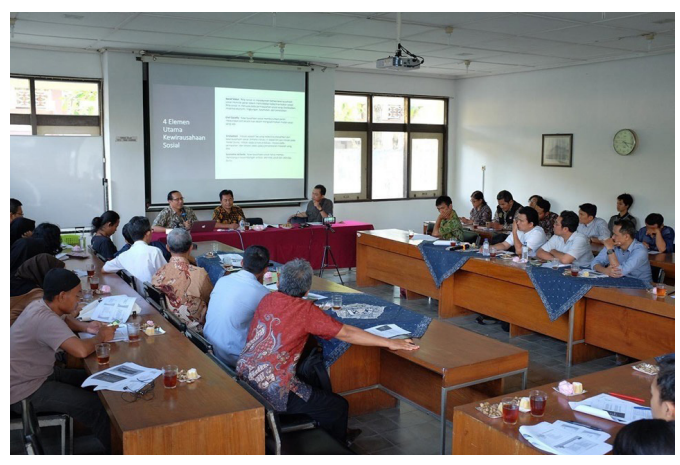

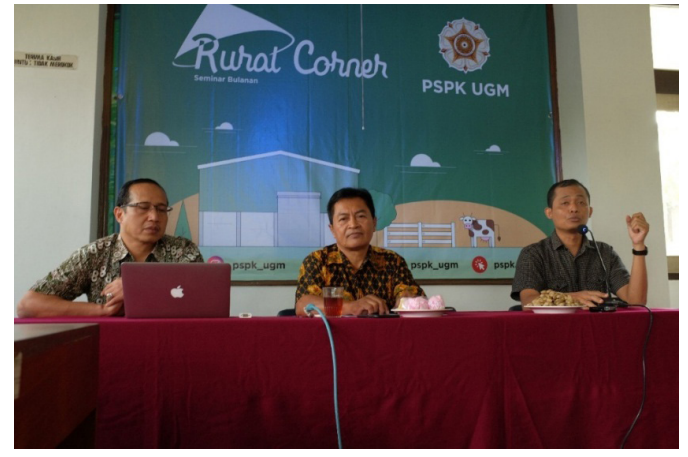

Gambar 2. Narasumber Dr. Suharko dan DC. Mulyono MA. sedang memberikan pemaparannya.

Gambar 3. Suasana diskusi kegiatan Pelatihan Penguatan Pengelola BUMDesa.

seluruh atau sebagian besar modalnya dimiliki oleh desa melalui penyertaan secara langsung yang berasal dari kekayaan desa yang dipisahkan guna mengelola aset, jasa pelayanan, dan usaha lainnya untuk sebesar-besarnya kesejahteraan masyarakat desa." Selaras dengan definisi tersebut maka semangat yang harus dimiliki oleh BUMDesa sebenarnya adalah semangat kewirausahaan sosial, dalam arti semangat untuk menjalankan usaha di desa demi terlaksananya pembangunan sosial dan pemberdayaan masyarakat.

Namun, realitas di lapangan menunjukkan bahwa sebagian besar BUMDesa memiliki orientasi yang menyimpang dari tujuan asal dan semata-mata bertujuan untuk memperoleh laba (profit) yang sebesar-besarnya. BUMDesa dinilai telah meninggalkan semangat kewirausahaan soaialnya dan beralih sebagai pelaku usaha, yang sematamata untuk mencari keuntungan. Jawaban atas permasalahan tersebut adalah perlunya REPOSISI dan REORIENTASI BUMDesa untuk usaha desa bagi rakyat, pembangunan sosial, dan pemberdayaan ekonomi masyarakat desa.

Banyak faktor yang menentukan apakah BUMDesa yang terbentuk dapat dinilai sukses dan gagal dalam mencapai tujuan yang diharapkan. Beberapa faktor penyebab suksesnya BUMDesa antara lain adalah kemampuan untuk mengidentifikasikan aset, potensi, kebutuhan, dan kegiatan ekonomi di Desa; keberadaan masyarakat desa yang aktif (active citizens); komitmen Pemerintahan Desa dalam mengelola BUMDesa dan sosialisasi secara tepat dan bertahap; adanya tim kajian atau persiapan yang bekerja secara maksimal; latar belakang pendirian yang kuat; keberadaan social enterpreneurs di desa; 
adanya entrepreneur bio (passion, keahlian, resilience, naluri bisnis, dan keterampilan manajemen); serta efektifnya kerja pendamping dan coaching.

Adapun beberapa faktor yang menjadi penentu kegagalan BUMDesa antara lain adalah kuatnya dominasi elite lokal; adanya konflik pengelolaan aset desa yang akut; pendirian BUMDes tanpa melalui proses Musyawarah Desa (Musdes) secara benar; pendirian yang tidak melalui proses kajian dan persiapan yang matang oleh tim; berorientasi jangka pendek; hanya berorientasi pada keuntungan (profit) dan PADes; masuknya BUMDesa ke bisnis yang persaingannya sudah ketat; didasarkan atas program top-down yang bersifat massal/ penyeragaman dari Pemda serta dikembangkan dengan take over atau akuisisi kegiatan ekonomi yang sudah berjalan sebelumnya.

Untuk mendorong agar BUMDesa memiliki semangat kewirausahaan sosial, setiap BUMDesa perlu didorong untuk mampu menjiwai empat elemen utama dari sebuah wirausaha sosial. Pertama, social value, dalam arti BUMDesa harus memiliki peran dalam menciptakan kebermanfaatan sosial sehingga mampu membantu menyelesaikan permasalahan sosial yang dihadapi warga masyarakat, seperti masalah ekonomi, lingkungan, kesehatan, dan pendidikan. Kedua, civil society, yaitu adanya peran masyarakat sipil secara luas dalam mengoptimalkan modal sosial yang sudah terbentuk dalam masyarakat, seperti keberadaan jaringan sosial, baik antarmasyarakat, pemerintah, LSM, maupun swasta, trust, maupun norma dan nilai yang berlaku. Ketiga, innovation, dalam arti adanya inovasi dalam berbagai aspek, misalnya inovasi dalam model bisnis, proses produksi, pemasaran, dan berbagai bentuk upaya penyelesaian persoalan yang ada. Keempat, economic activity, dalam arti menumbuhkembangkan aktivitas ekonomi yang mampu membangun keseimbangan antara aktivitas sosial dan aktivitas bisnis.

Dalam sesi diskusi, salah satu peserta pelatihan menyatakan rasa keheranan atas sikap pengelola BUMDesa teladan yang mau menjadi pengurus BUMDesa dengan honor yang sangat kecil. Selain itu, ia juga bertanya mengenai peluang warga untuk memiliki saham dalam BUMDesa sehingga ia juga mendapatkan dividen. Menanggapi pertanyaan tersebut, narasumber menceritakan bahwa keberhasilan sebuah BUMDesa diawali dari adanya orang "gila" yang mau berkorban untuk mengembangkan BUMDesa. Tanpa adanya orang yang mampu bedarah-darah untuk mengembangkan BUMDesa, peluang BUMDesa untuk maju sangat kecil. Ia juga menyatakan bahwa BUMDesa harus mampu menyeimbangkan orientasi sosial dan orientasi ekonomi. BUMDesa harus mampu berbisnis, tetapi juga mampu berbagi kepada warga masyarakat. Peserta yang lain menyampaikan pertanyaan tentang cara menciptakan model bisnis untuk satu wilayah dan cara menjaga kepercayaan masyarakat terhadap pengurus BUMDesa yang mengelola aset miliaran. Menanggapi pernyataan dan pertanyaan peserta, Dr. Suharko menyatakan bahwa kesulitan dalam mendirikan BUMDesa adalah menemukan aktor di desa yang siap berjuang untuk mengembangkan

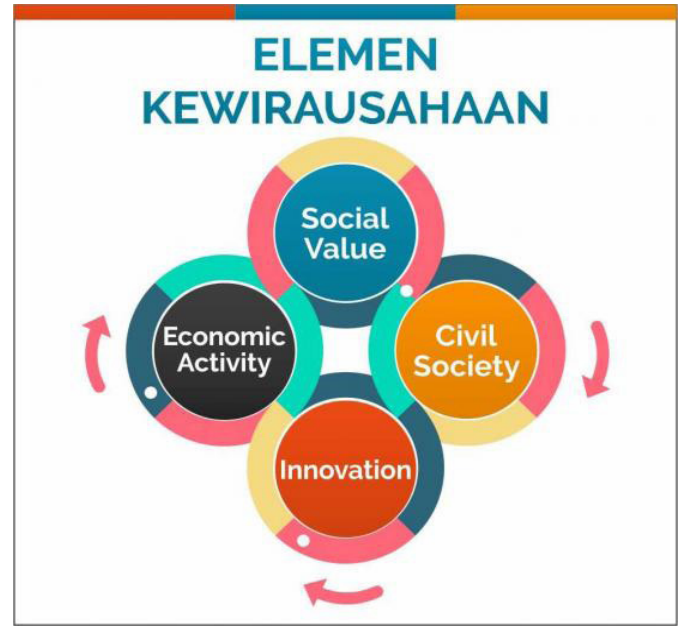

Gambar 4. Elemen Kewirausahaan Sosial. 
BUMDesa. Salah satu cara yang dapat dilakukan untuk mengatasi persoalan tersebut adalah dengan melakukan sosialisasi tentang BUMDesa dengan melibatkan banyak pihak. Berdasarkan pengalaman, aktor bisa ditemukan dari lembaga desa atau tokoh masyarakat.

BUMDesa Karangrejek sudah menunjukan kewirausahaan sosial dari pengelolaan air bersih yang dilakukan karena tarif ditentukan berdasarkan musyawarah dengan warga. Selain itu, BUMDesa sudah melakukan pembangunan sosial melalui program ambulans gratis, biaya pemakaman, dan beasiswa bagi anak dari kalangan tidak mampu. Sementara itu, cara menciptakan bisnis model adalah dengan identifikasi potensi dan aset, pemetaan aktor, dan penentuan bisnis. Sementara itu, dinyatakan bahwa semangat yang harus dibangun oleh pengelola BUMDesa adalah semangat pengabdian. Pengurus BUMDesa yang memiliki semangat untuk mengabdi tidak akan mempermasalahkan honor yang kecil. Namun, apabila BUMDesa sudah mampu, kesejahteraan pengurus dan karyawan juga perlu diperhatikan. Untuk menjaga kepercayaan warga, keuangan BUMDesa dikelola secara transparan dan akuntabel, yakni, antara lain dengan membuat laporan setiap bulan dan diaudit oleh kantor akuntan secara periodik.

\section{Kegiatan Kunjungan Lapangan}

Kegiatan kunjungan lapangan dilaksanakan pada Senin, 7 Oktober 2019 di desa Karangrejek, Kecamatan Wonosari, Kabupaten Gunung Kidul. Lokasi tersebut dipilih karena memiliki BUMDesa yang bervisi wirasusaha sosial. Sebelum memiliki BUMDesa, Desa Karangrejek merupakan desa yang masuk kategori IDT, terisolasi, dan sering mengalami kekeringan. Disebut sebagai desa miskin karena dari 900 rumah, hanya 136 rumah yang bersifat permanen (berdinding tembok), sedangkan sisanya merupakan rumah semipermanen (sebagian tembok, sebagian gedek). Sebagian besar warga masyarakat bekerja sebagai buruh serabutan atau buruh tani dan hanya 16 orang yang bekerja sebagai pegawai negeri. Hanya sedikit warga yang mampu mencapai pendidikaan perguruan tinggi, sedangkan sebagian besar pemuda lebih memilih merantau daripada melanjutkan pendidikan ke perguruan tinggi selepas sekolah. Desa dianggap terisolasi karena tidak ada jalan, listrik, dan air.

Menyadari kondisi desa yang memprihatinkan tersebut maka beberapa tokoh masyarakat yang memiliki kepedulian untuk memajukan desa berinisiatif untuk membentuk BUMDesa. Salah satu jenis usaha yang dipilih adalah penyediaan air bersih (PAMSIMAS). Pada saat memilih jenis usaha tersebut terdapat banyak kendala, yakni, antara lain, tantangan dari tokoh masyarakat dan sebagian besar warga masyarakat akibat kondisi alam Desa Karangrejek yang tidak memiliki sumber mata air. Untuk mengatasi kendala tersebut, tokoh masyarakat berencana melakukan pengeboran air tanah. Meski rencana tersebut ditentang oleh banyak pihak, mereka tetap melakukan pengeboran air tanah hingga kedalaman $150 \mathrm{~m}$. Mereka berhasil mendapatkan air tanah, tetapi kendala lain yang dihadapi adalah ketiadaan pompa yang mampu menaikkan air tanah tersebut. Untuk mengatasi hal tersebut, mereka merencanakan membeli pompa air senilai 450 juta rupiah, tetapi BUMDesa tidak memiliki dana yang cukup. Mereka mencoba mencari pinjaman ke bank, tetapi tidak ada bank yang bersedia memberikan kredit sebesar itu. Mereka terpaksa mengumpulkan iuran dari beberapa pengurus BUMDesa. Namun, karena dana yang terkumpul relatif kecil, akhirnya mereka memutuskan untuk 
mengumpulkan sertifikat tanah dari beberapa pengurus BUMDesa dan dijadikan sebagai agunan untuk mendapatkan pinjaman dari perseorangan. Dana pinjaman tersebut dipakai untuk membeli pompa dan untuk membangun bak penampungan air serta membeli pipa jaringan. Sementara itu, untuk memasang pipa jaringan, mereka mengajak warga masyarakat untuk bergotong royong. Setelah jaringan terbangun, selain mengajak warga desa untuk berlangganan air, mereka juga mengajak warga dari desa lain. Dari pengelolan air PAMSIMAS tersebut akhirnya BUMDesa memperoleh penghasilan rutin yang mencapai puluhan juta per bulan.

Setelah keuangan BUMDesa kuat, tokoh masyarakat bersama pengurus lainnya berencana melakukan diversifikasi usaha BUMDesa, yaitu simpan pinjam, agribisnis pertanian, dan rest area. Banyak faktor yang menjadi pertimbangan dalam memilih jenis usaha baru tersebut. Kegiatan simpan pinjam dipilih untuk melepaskan warga masyarakat dari jeratan rentenir atau bank plecit, sedangkan agribisnis pertanian dipilih untuk melepaskan para petani dari tengkulak atau pengijon yang sering merugikan petani karena membeli hasil pertanian dengan harga rendah, sementara rest area dipilih karena lokasi Desa Karangrejek yang strategis, yakni terletak di Jalan Wonosari dan Pantai Baron. Selain melakukan diversifikasi usaha, BUMDesa Karang rejek juga melakukan pembangunan sosial dan pemberdayaan masyarakat, yakni, antara lain dengan menyediakan fasilitas ambulans gratis bagi warga desa yang sakit dan ingin berobat ke rumah sakit serta untuk mengangkut warga yang meninggal dunia. Selain itu, BUMDesa juga memberikan dana pemakaman bagi warga yang meninggal dunia. Tidak hanya itu, BUMDesa juga memberikan beasiswa bagi anak-anak sekolah dari kalangan warga kurang mampu.

Dalam sesi diskusi, seorang peserta kunjungan lapangan menyampaikan pertanyaan terkait dengan pilihan usaha pengelolaan air bersih sebagai jenis usaha dari BUMDesa Karangrejek. Menanggapi pertanyaan tersebut, pengurus BUMDesa Karangrejek menyampaikan bahwa pemilihan tersebut didasari oleh fakta bahwa di desa tersebut, air bersih merupakan kebutuhan mendasar setiap warga masyarakat yang sulit dipenuhi. Dalam hal ini, BUMDesa Karangrejek telah menunjukkan visi kewirausahaan sosial dengan mengembangkan usaha yang memberi manfaat sosial (social value) bagi masyarakat. Pilihan usaha ini merupakan respons atas ketidakmampuan pihak pemerintah (public sector) dan swasta dalam penyediaan air bersih bagi masyarakat.

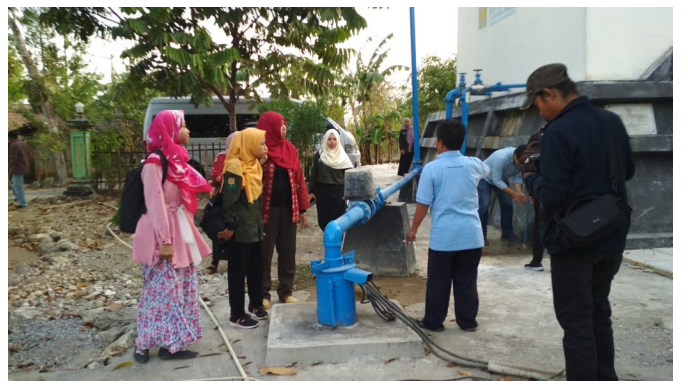

Gambar 5. Kunjungan Lapangan di Desa Karangrejek, Kecamatan Wonosari, Kabupaten Gunung Kidul.

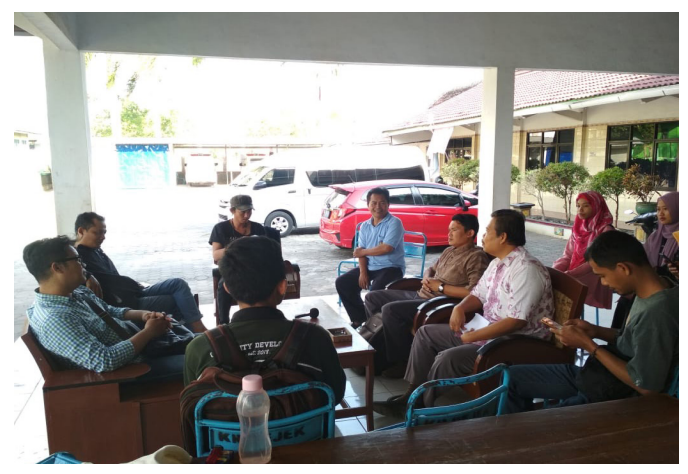

Gambar 6. Sesi Diskusi di Lapangan. 
Pilihan usaha ini juga telah meningkatkan kesejahteraan masyarakat karena dapat mencegah hilangnya aset ekonomi berupa ternak, tabungan, atau perhiasan untuk membeli air. Selain itu, usaha pengelolaan air bersih mampu membawa dampak ikutan (multiplier effects) dalam peningkatan kegiatan ekonomi di Desa Karangrejek, seperti munculnya usaha makanan, laundry, cuci mobil, perikanan, dan pertanian.

Peserta lain menyampaikan pertanyaan terkait dengan modal sosial, khususnya tentang strategi pengurus BUMDesa Karangrejek dalam menjaga kepercayaan masyarakat. Menanggapi pertanyaan tersebut, pengurus BUMDesa menyampaikan bahwa untuk membangun kepercayaan masyarakat, pengurus membuat laporan kondisi keuangan, yaitu laporan bulanan serta laporan pertanggungjawaban dengan menyertakan hasil audit independen setiap tahun.

Terkait dengan indikator aktivitas ekonomi, salah satu peserta menanyakan tentang keseimbangan antara usaha bisnis dan sosial di BUMDesa Karangrejek. Menjawab pertanyaan tersebut, pengurus BUMDesa Karangrejek menyatakan bahwa BUMdesa telah menyeimbangkan keduanya dengan hal-hal berikut. Pertama, menetapkan harga jual air di bawah harga standar PDAM berdasarkan kesepakan warga. Kedua, pembelian komoditas produk pertanian dengan harga tertentu untuk memutus rantai pemasaran yang dikuasai oleh tengkulak. Ketiga, simpan pinjam dengan tingkat suku bunga yang terjangkau oleh masyarakat guna menghilangkan ruang gerak rentenir yang selama ini menjerat warga. Keempat, pembangunan rest-area untuk memberi akses pada UKM lokal yang ingin membuka usaha. Kelima, kegiatan sosial yang didanai oleh BUMDesa, seperti beasiswa, pengadaan ambulans, pemberian dana pemakaman, renovasi masjid, dan sponsor aktivitas olahraga.

Dari aspek inovasi, pertanyaan juga muncul dari salah satu peserta mengenai inovasi yang selama ini telah dilakukan BUMDesa Karangrejek. Pengurus menjawab bahwa inovasi yang pernah dilakukan berkaitan dengan inovasi model penyelesaian masalah kredit macet. Pengurus membentuk tim percepatan pengembalian pinjaman yang beranggotakan beberapa tokoh masyarakat, yang bertugas mendorong warga yang memiliki kredit macet di unit simpan pinjam BUMDesa untuk segera melunasi pinjaman. Salah satu langkah yang dilakukan oleh tim adalah dengan melakukan kunjungan secara rutin kepada warga yang memiliki kredit macet. Selain itu, tim juga menyampaikan daftar warga yang memiliki kredit macet kepada pemerintah desa agar ketika warga yang bersangkutan meminta fasilitasi kepada pemerintah desa, mereka diwajibkan untuk melunasi kreditnya terlebih dahulu.

Dari kegiatan kunjungan dan diskusi di atas, peserta dapat menilai bahwa BUMDesa Karangrejek telah memilik visi wirausaha sosial sehingga ke depan, peserta bisa mereplikasi langkah-langkah pengembangan BUMDesa yang bervisi wirausaha sosial di daerahnya masing-masing.

\section{Refleksi Capaian Program}

Kegiatan pengabdian kepada masyarakat berupa pelatihan penguatan BUMDesa bervisi wirausaha sosial berhasil dilaksanakan dengan baik. Beberapa indikator yang menunjukkan keberhasilan tersebut adalah sebagai berikut. Pertama, tingkat kehadiran peserta, baik dalam sesi pelatihan maupun kunjungan lapangan, mencapai di atas $80 \%$. 
Kedua, tingkat keaktifan peserta dalam mengikuti pelatihan dan kunjungan dinilai baik. Hal itu ditunjukkan dengan banyaknya pertanyaan dan tanggapan dari peserta. Ketiga, komitmen para peserta dalam menerapkan hasil pelatihan dalam pengelolaan BUMDesa bervisi wirausaha sosial.

Adapun manfaat kegiatan pengabdian kepada masyarakat yang sudah terlihat antara lain adalah sebagai berikut. Pertama, adanya kesediaan peserta untuk mengubah orientasi dan peran BUMDesa dari usaha desa untuk pemerintah desa menjadi usaha desa untuk rakyat desa. Kedua, kesediaan peserta untuk melakukan sinergisasi BUMDesa sebagai upaya peningkatan kesejahteraan masyarakat, khususnya dalam pengembangan ekonomi lokal. Ketiga, kesediaan peserta untuk mengembangkan BUMDesa yang bervisi wirausaha sosial.

\section{Penutup}

Rekomendasi yang dihasilkan dari kegiatan pengabdian kepada masyarakat terkait dengan pengembangan BUMDesa bervisi wirausaha sosial adalah sebagai berikut.

1. Mengubah pola pikir (mindset) pengurus BUMDesa

Pola pikir (mindset) merupakan energi dalam sebuah langkah usaha. Sebuah cara berpikir negatif akan membuat energi tim pengelola BUMDesa terkuras demi mengurusi beberapa persoalan yang sebenarnya tidak terlalu penting dan bisa diatasi. Dalam menjalankan BUMDesa, cara berpikir negatif harus disingkirkan, seperti mengurangi kekhawatirkan akan kekurangan dana, adanya penolakan dari masyarakat, ketiadaan potensi dan aset desa, minimnya peluang usaha yang berbasis pada kebutuhan masyarakat, dan lain-lain. Pola pikir positif akan memunculkan energi untuk mencari solusi, seperti masalah kekurangan dana dapat diatasi dengan memulai usaha dengan dana yang ada secara terukur. Jika masyarakat menolak, hal itu dapat diatasi dengan upaya sosialisasi secara tepat dan bertahap. Jika desa tidak memilki potensi, mungkin perlu dilihat dari sudut pandang yang lain. Pola pikir positif merupakan kunci sukses BUMDesa. Cara membentuk pola pikir positif adalah dengan mengenali potensi desa, belajar dari BUMDesa yang telah berhasil, memiliki kemampuan untuk membaca peluang bisnis dari kebutuhan masyarakat, serta terus mengikuti berbagai pelatihan yang diberikan.

2. BUMDesa diisi oleh tim pengelola yang solid dan tekun

Duet atau kombinasi dari orang-orang dengan otak kanan yang dominan (kreatif, berani mengambil risiko, dan trengginas) dengan orang-orang yang dominan otak kiri (sistematis serta penuh pertimbangan dan kehati-hatian) akan membawa BUMDesa yang sukses berkelanjutan. Pengurus BUMDesa harus mengerti bahwa usaha ataupun bisnis yang mereka jalankan pasti memerlukan waktu sehingga membutuhkan kerja secara kontinu. Pengurus BUMDesa harus memiliki ketekunan yang luar biasa untuk merintis BUMDesa yang bervisi wirausaha sosial.

3. BUMDesa bergerak di bidang yang memiliki manfaat sosial yang kuat BUMDesa harus mampu memetakan adanya kemacetan atau kebutuhan mendesak dalam kehidupan masyarakat sehingga BUMDesa mampu menyediakan jalan keluar dari kemacetan atau kebutuhan tersebut, seperti kebutuhan warga akan listrik, air bersih, pengelolaan sampah, modal usaha, pendidikan, potensi wisata, 
maupun kesehatan. BUMDesa harus mampu menemukan sektor mana yang tidak berfungsi, memecahkan masalah dengan mengubah sistemnya, menyebarluaskan pemecahannya, dan meyakinkan seluruh masyarakat untuk berani melakukan perubahan.

4. Mampu menarik partisipasi masyarakat secara luas

BUMDesa harus memiliki komitmen untuk senantiasa menghargai dan menggunakan kearifan lokal dalam mendayagunakan potensinya serta menyerap kekuatan masyarakat dalam setiap proses produksi atau usaha yang dilakukan. BUMDesa harus bisa mengelola segala potensi dan aset desa yang dimilikinya dengan baik. Di samping itu, BUMDesa harus mampu merangkul dan bermitra dengan semua stakeholder, mulai dari masyarakat, pemerintah, LSM, maupun sektor swasta.

\section{Daftar Pustaka}

Chambers, R. (1994). "The Origins and Practice of Participatory Rural Appraisal". World Development, Volume 22 (7), 953-969.

PKDSP Fakultas Ekonomi Unbra. (2007). Buku Panduan dan Pembentukan Badan Usaha Milik Desa (BUMDes). Malang: PPRPDN.

Gaventa, J. (2005). "Enam Sasaran Proposisi Menuju Tata Pemerintahan Daerah Partisipatoris", dalam Sugeng Bahagio dan Rusdi Tagaroa (eds.), Orde Partisipasi (1-21). Jakarta: Perkumpulan Prakarsa.

Hudayana, B. (2017). Pemberdayaan Masyarakat, Bunga Rampai Antropologi Terapan. Yogyakarta: Pustaka Pelajar.

Koentjaraningrat. (1997). Kebudayaan Mentalitas dan Pembangunan. Jakarta: Gramedia Pustaka Utama.

Mikkelsen, B. (2011). Metode Penelitian Parttisipatoris dan Upaya Pemberdayaan. Jakarta: Yayasan Pustaka Obor Indonesia.

Narayan, D. (2002). Empowerment and Poverty Reduction. Washington, DC: The World Bank.

Prijono, O. \& Pranarka (ed). (1996). Pemberdayaan, Konsep, Kebijakan dan Impementasi. Jakarta: Centre for Strategic and International Studies.

Spardley, J. J. (1979). The Ethnographic Interview. New York: Holt, Renehart and Winston. Utomo, H. (2014). "Menumbuhkan Minat Kewirausahaan sosial". Among Makarti, Vol. 7 (14), 1-16. 